\title{
Marketing Strategies and Export Performance of Fresh Produce Firms in Kenya
}

\author{
Anne Njonjo \\ PhD Candidate, Faculty of Business and Management Science, University of Nairobi \\ https://orcid.org/0000-0002-6916-7293 \\ Winnie Njeru \\ Faculty of Business and Management Science, University of Nairobi \\ https://orcid.org/0000-0001-6270-8336 \\ Francis Kibera \\ Faculty of Business and Management Science, University of Nairobi \\ https://orcid.org/0000-0001-7093-1992 \\ Joseph Owino \\ Faculty of Business and Management Science, University of Nairobi \\ https://orcid.org/0000-0002-4735-5533
}

Received: 28 September 2021/ Revised: 24 November 2021/ Accepted: 29 November 2021/

Published online: 30 December 2021

\begin{abstract}
The study objective was to examine the role of marketing strategies on export performance of fresh produce firms in Kenya. A major stream of research has considered marketing strategy and performance within the context of a domestic economy. A census survey was carried out among all the 100 fresh produce firms that were ordinary members of the Fresh Produce Export Association of Kenya (FPEAK) as at $31^{\text {st }}$ June 2019. The study utilized a positivist approach. Primary data were collected using a structured questionnaire. A descriptive cross-sectional study design was adopted.

The results of regression analysis revealed that the relationship between marketing strategies and export performance was positive and statistically significant. To policy makers, the study recommends regional and bilateral trade agreements that seek to increase the market share for fresh produce firms. To management practice, the study provides guidelines on how to design and implement sustainable but competitive marketing strategies for the export market. For future research direction, the study recommends additional moderating/mediating variables that may influence export performance.
\end{abstract}

JEL classification: M30, M31, N57, N77

Keywords: marketing strategies, export performance, marketing mix, exports 


\section{INTRODUCTION}

Globalization and intense competition have created many business opportunities for organizations eager to expand. As a result, more firms are increasingly pursuing international markets to safeguard their market position, increase their market share as well as boost corporate revenue in the long term (Chang \& Fang, 2015). Marketing strategy has been identified as one of the intrinsic components behind the success of firms in export markets (Fang \& Zou, 2009). It constitutes various marketing mix elements that translate marketing planning into practices. Entering new territories and conducting business in less familiar environments is however not easy. Hence, there is growing interest among businesses in understanding factors that contribute to the success of local firms in foreign markets.

Exporting remains the most preferred mode of foreign market entry particularly among small and medium-sized enterprises (SMEs). Jones (2001) contends that it is the first step to internationalization. This is because it involves low risk, requires minimal financial commitment and permits greater flexibility and ability to adapt when compared to other modes of entry (Leonidou, Katsikeas, \& Coudounaris, 2010). At the macro level, export business impacts critical areas such as foreign exchange earnings, employment opportunities and enhances societal prosperity (Abou-Strait, 2005). At the micro level, on the other hand, export trade is considered a strategic business tool used to boost corporate growth, diversify business risks and even take on foreign competitors (Okpara, 2010). Despite the potential gains that accompany export trade, many firms seem to have little knowledge on how to maximize the benefits derived from export business.

\section{RESEARCH PROBLEM}

The fresh produce industry has continued to experience unprecedented growth to become one of Kenya's leading export earner. In 2018, export earnings from this industry grew to Kshs 153.68 billion, a 33\% growth over 2017 earnings (Kenya National Bureau of Statistics, 2018). Despite this rapid and sustained growth, the above figures represent only $4 \%$ of the produce exported, which is way below the industry potential. Further, it is estimated that more than 4.5 million Kenyans benefit directly from the fresh produce industry and another 3.5 million benefit indirectly through trade and other related activities (KDLC, 2010). An increase in export performance would result in improved nutrition, more foreign exchange earnings and income generation opportunities. Despite the significance of fresh produce firms to the economy, knowledge on how to develop and implement marketing strategies for the export market remains scarce. Furthermore, studies that examine the role of marketing strategies in influencing export performance within the fresh produce industry are few. This study therefore sought to investigate how fresh produce firms can develop and implement competitive marketing strategies for the export market.

\section{EMPIRICAL LITERATURE REVIEW}

\subsection{Marketing Strategies and Export Performance}

Empirical studies on the link between marketing strategy and export performance are many. However, divergent and inconsistent findings have been reported. Sousa and Bradley (2008) collected data from 301 exporting firms in Portugal. The study results indicated that price had a significant impact on export performance. A similar outcome was obtained by Chung (2008), who conducted a survey on a sample of 78 SMEs in New Zealand. These two studies examined 
pricing in isolation from the other marketing mix variables. The current study took into account the 4Ps of marketing strategies as a unified whole, resulting in a clearer view of marketing strategy, particularly in an export marketing context. Sezgin, Uray and Burnaz (2015) did a survey of 100 clothing firms located in Istanbul, Turkey. The findings from the study revealed that marketing strategies contributed to the success of Turkish clothing firms in international markets. The study findings were however limited to the Turkish clothing industry, hence the results could not be generalized beyond this scope. In Chile, Bianchi and Garcia (2007) carried out an investigation on three sectors, namely: fruit, salmon and wine. Data was collected using secondary sources as well as qualitative methods. Top performers revealed that emphasis on product quality, promotion and product diversification contributed to the success in export performance. Similarly, Namiki (2008) examined the marketing strategy and export performance relationship of US electronic export firms. Out of a sample of 316 manufacturers of electronics, 99 (31\%) responded. The results from the study revealed existence of a close link between a firm's marketing strategy and export performance. Studies by Bianchi and Garcia (2007) and Namiki (2008) were exploratory in nature, thereby limiting generalization of findings to the entire population.

In Nigeria, Ogbu (2015) carried out a study on the marketing strategies adopted by quantity survey firms. Focus group discussions as well as secondary sources of data were obtained. The findings from the study depicted that marketing strategies are key to attaining higher firm performance. In another study, Nthege (2019) conducted a survey on 64 manufacturing firms in Kenya. The results from the study established that marketing strategies influenced performance. Studies by Nthege (2019) and Ogbu (2015) were confined to performance within the domestic market. The current study extends previous marketing strategy-performance relationship by investigating marketing strategies within an international context.

In another study, Odiko (2018) considered the role of marketing strategy in international performance of 270 tour firms in Kenya. The findings from the study revealed that success in international markets depends on the firm's marketing strategy. The study findings were confined to the tourism industry, which is a different environment from the fresh produce industry. In Malaysia, Adis (2010) examined the role of marketing strategy in influencing export performance. The research findings revealed that all the 4Ps of marketing strategy did not influence performance of firms in foreign markets. These results were however limited to firms in Malaysia within the wood furniture industry. Shoham and Kropp (1998) carried out an evaluation in the United States on the marketing mix and international performance relationship. The study results revealed that marketing elements had a negative effect on export performance except for channel support which had a positive relationship. This study was characterized by a $(5 \%)$ response rate, which was considered low for a mail survey. The use of small samples questions external validity and generalization of findings, hence the need for a more rigorous empirical research.

In Canada, Coviello, Winklhofer and Hamilton (2006) collected data from 242 firms in the accommodation industry. The findings from the study revealed that contemporary marketing practices (CMP), specifically network marketing, data base marketing and e-marketing, did not have any influence on performance. This study was in the service industry and conceptualized marketing strategies along the contemporary marketing practices framework (CMP). The current study was in the goods industry and conceptualized marketing strategies using the traditional 4Ps believed to be the theoretical framework for developing marketing strategies. Most of the empirical studies have dealt with one element of the marketing mix, were conducted in developed economies, were exploratory, used small samples resulting in inconsistent findings. Hence the need to investigate the marketing strategy and export performance relationship using a more rigorous research. 


\subsection{Export Performance}

Export performance is the extent to which an organization's objective is achieved by selling goods/services in overseas markets (Cavusgil \& Zou, 1994). On their part, Navarro, Losada, Ruzo and Diez (2010) contend that export performance is the consequence of an organization's action in international markets and is considered one of the key indicators of success in foreign markets. To capture export performance, two principal measures are used: objective and subjective measures. Objective indicators can also be seen as financial metrics such as revenue, profit, sales volume measures often expressed in monetary terms. The subjective measures are indicators such as customer loyalty, quality of services and firm reputation which provide performance information in non-monetary terms. They particularly focus on meeting customer expectations, satisfaction and marketing activities (Köksal \& Kettaneh, 2011).

Export literature has viewed measures of export performance from different perspectives. Zou, Taylor and Osland (1998) introduced the EXPERF scale, which measured performance using three basic dimensions, namely: financial, strategic and satisfaction. Later on, Lages and Lages (2005b) proposed the STEP scale which measured export performance for a single product or product line in the short term. The STEP scale was however limited to the use of subjective performance indicators. Okpara's (2009) scale used five items, namely: export profits, sales volume, export growth, operations and overall export performance in the last three years.

In the current study, export performance was measured using one objective measure, namely return on assets (ROA), and two subjective indicators, namely export market share and customer retention rate. ROA is a measure of how efficiently the firm uses its assets to generate profits. The main indicators are net income and total assets. ROA was adopted in this study as it enables the comparison of firms in the same industry, but of different sizes. The export market share and customer retention rate were based on the premise that a positive disposition towards a product is a measure of subsequent long-term use (Lages \& Sousa, 2010).

\subsection{Marketing Strategy}

Marketing strategy as defined by Kotler (2011) is a road map that outlines how the firm is going to achieve its marketing objectives in a competitive business environment. Rad and Akbari (2014) agree that marketing strategy is a guide used by firms to allocate resources, differentiate themselves while satisfying customer needs better than competition in a specific market segment.

Thus, from the above definitions, marketing strategy is centered around identifying a target market and satisfying customers in those segments better than competition. The focus on a particular market segment results in more experience, which is communicated to the customer through low prices, products differentiation and product quality.

The concept of marketing strategy revolves around a set of controllable tools, namely product, price, promotion and place used by a firm to influence buyer response. In this study, marketing strategy can be seen as a tool used by firms to differentiate themselves from competition, build market reputation and establish strong relationships with customers. Marketing strategy was the independent variable with product, price, place and promotion as its indicants.

\subsection{Product Strategies}

Products are goods and services offered in the market to satisfy a need or want (Kotler \& Armstrong, 2014). Product is the most significant element of the marketing mix which must be properly developed to meet the needs of the consumers and achieve the firm's objectives. Apart from the actual goods and services, attributes such as the physical appearance, packaging and labeling information make up what the customer is actually buying and are used to enhance 
customer experience (Belch \& Belch, 2007). To achieve success, managers should think about product development on three levels. The first is the core product which answers the question of product benefits to the customer. The second level is the actual product which refers to product quality, design, brand name that enhances the core product. The third level is the augmented product which refers to additional non-tangible benefits such as after-sales service, warranties, free delivery that a firm can offer to influence consumer purchase decision (Kotler \& Armstrong, 2005). According to Mohammad, Wang and Sunayya (2012), marketers should identify products features and attributes that enhance consumer experience and convert them into a unique selling proposition. A unique product provides a firm with a competitive advantage over its rivals. This study hypothesized that:

$H_{1}$ : Product strategies adopted by firms have no significant influence on their export performance.

\subsection{Pricing Strategies}

Price represents the amount of economic outlay that consumers should give up to engage in a given transaction. Price determines the profits earned as well as the competitiveness of a product in the market. It however remains one of the most challenging decisions in marketing due to increased competition (Myers, 1997). According to Blattberg and Scott (1990), price features such as discount, allowances, and credit terms should be thought of well in advance. Price is not only used as an element of financial sacrifice but also to communicate product quality. A highly priced product may result in poor sales, while a lowly priced product may be misleading on product attributes such as performance, quality (Hinterhuber \& Liozu, 2013). A pricing strategy takes into account market conditions, elasticity of product, customer perspectives and competition (Cram, 2006). Consequently, this study posits that:

$\mathrm{H}_{2}$ : Pricing strategies have no significant influence on marketing strategies adopted by firms.

\subsection{Promotion Strategies}

Kotler (1989) described promotion as a set of activities used to increase consumer awareness, boost sales and build brand loyalty in the target market. Shimp (2003) agrees that promotion activities boost sales in the short term and are used to convince customers to choose one brand over another. The promotion element consists of elements such as advertising, public relations, sales promotion, personal selling, direct marketing, events and sponsorship (Belch \& Belch, 2007). Additional promotion elements include influencer marketing, podcasting, branded entertainment (Satish, 2006). The incorporation of the promotional elements is called integrated marketing communication or IMC. Kotler (1977) posits that for marketers to effectively communicate with customers, they need to first study and understand consumer behavior. For the purposes of this study, the focus will be on international trade fairs. This was grounded on previous export literature that used international trade fairs as indicators of promotion strategy. According to Madsen (1987), the majority of studies that used international trade fair as an indicator established a positive association between promotion and export performance. International trade fairs are believed to reduce buyer uncertainty and culture differences. Hence, this study put forward the following hypothesis:

$H_{3}$ : Promotion strategies adopted by firms have no significant influence on their export performance. 


\subsection{Place (Distribution) Strategies}

Place as defined by Palmer (2011) is the decisions and actions related to making products or services available for consumption. Bowersox and Closs (1996) describes distribution as another name for place and confirms that it is the mechanism by which a good or service is made available for consumption. Wholesalers, retailers, distributors and the internet are examples of distribution channels. Mallen (1977) argues that the type of distribution channel depends on the distribution goals which can be classified into minimum distribution costs, maximum bargaining power and optimum access to markets. In an international business context, factors such as culture, government restriction, competition, increased distance (both physical and psychic) result in more complex distribution channel relationships than those in domestic markets (Rosenbloom, 1990). The following hypothesis was tested:

$H_{4}$ : Distribution has no significant influence on firms' export performance.

\subsection{Conceptual Framework}

The conceptual model presented in Figure 1 is derived from concepts discussed in the literature review. The model depicts the relationship between marketing strategy elements, namely product, price, promotion, place, and export performance.

Figure 1

Conceptual Model

Independent Variables

Dependent Variable

\begin{tabular}{|c|c|c|}
\hline Product strategies & $\mathbf{H}_{1}$ & \\
\hline Pricing Strategies & $\mathbf{H}_{2}$ & $\begin{array}{l}\text { Export Performance } \\
\cdot \text { ROA }\end{array}$ \\
\hline Promotion Strategies & $\mathbf{H}_{3}$ & - Customer Retention Rate \\
\hline Place (Distribution Strategies) & $\mathbf{H}_{4}$ & \\
\hline
\end{tabular}

\section{RESEARCH METHODOLOGY}

\subsection{Population of the Study}

The population of the study was developed from the Fresh Produce Exporters Association of Kenya (FPEAK) website, a source that provides regularly updated information of its members, firm demographics as well as contact person. A total of 100 fresh produce firms that were members of the association as at $31^{\text {st }}$ June 2019 were selected for the study. FPEAK is a body that promotes export activities through overseas exhibitions, providing market information, technical support and training. Fresh Produce Exporters Association of Kenya (FPEAK) has been used in related studies (Wanjiru, 2018; Kabano, 2017).

Fresh produce firms are spread across the country, but are predominant in Nairobi, which is the main industrial hub of Kenya. Given the relatively small size of the population, a census study was undertaken on all 100 fresh produce firms. Israel (1992) argues that a census technique is preferred when the population is made up of 200 or fewer members. The Chief Executive Officers, Managing Directors or Top Line Managers in charge of export operations were the key informants in each fresh produce company. The choice of respondents was influenced by their roles within the firms, which indicated that they had the knowledge and understanding about the firm's marketing strategies. 


\subsection{Questionnaire Design and Administration}

A semi-structured questionnaire adapted from previous empirical surveys was used to collect data on the key study variables. However, some questions were modified to suit the specific research objectives. The advantage of consulting questionnaires used in previous studies is that they are less susceptible to misinterpretation and can also be used to compare findings. The questionnaire consisted of five major sections. Section 1 collected background information on both the firm and respondent. Section 2 focused on marketing strategies and was measured using four dimensions (product, pricing, distribution and promotion). The last section focused on export performance and used measures such as export market share, customer retention rate and ROA.

\subsection{Operationalization of the Study Variables}

Each study variable was operationalized using measures developed from previous studies. Marketing strategies is the independent variable and was measured using 28 attitudinal attributes derived from previous studies, an extensive review of literature and export marketing text books (Njeru, 2013; Morgan, Katsikeas, \& Vorhies, 2012). However, several modifications were made to take into account specific characteristics within the fresh produce industry. Export performance is the outcome variable and was measured using subjective/perceptual measures as has been used in several other studies (Lisboa, Skarmeas, \& Lages, 2013; Murray, Gao, \& Kotabe, 2011). Several factors support the use of subjective measures. First, differences in market characteristics, technology intensity may lead to an unfair comparison of financial data which may have different meaning to various firms. Second, most studies adopt perceptual measures to measure financial performance since secondary information is often not available for public consumption (Lages \& Lages, 2004; Kimwomi, 2014). Third, according to Katsikeas et al. (2000), indicators of performance are more complementary than mutually exclusive. Therefore, subjective measures were adopted in this study.

\subsection{Validity Tests}

Validity refers to whether or not a test accurately measures what it purports to measure (Saunders, 2011). There are various methods used to test validity, namely: content validity, face validity and convergent validity (Babbie, 2010). To evaluate content validity, ten fresh produce firms were randomly selected and thereafter a pilot study was conducted. According to Hair, Ringle and Sarstedt (2011), a pretest of 5 to 10 respondents is useful in identifying flaws in a questionnaire. Feedback was requested on all items of the questionnaire including length, cognitive aspects, layout and order of the questionnaire. The findings from the pilot revealed that eight out of the ten fresh produce firms had reservations about providing actual financial data on return on investment (ROA). In other instances, respondents had difficulty in understanding certain questions. Based on the feedback, some of the questions were rephrased and questions on financial data were assessed with the help of a Likert-type scale.

Construct validity provides the researcher with confidence that the items in the survey instrument measure the constructs they propose to measure. In practice, constructs are not readily observable items. In this survey, construct validity was established using an exploratory factor analysis (EFA). Hare and Neumann (2008) argue that factor analysis reduces the overall number of observations into a few variables that can best explain the constructs under investigation. To determine the appropriateness of the sample for EFA, Kaiser-Meyer Olkin (KMO) measure, sample size and Barlett's test of sphericity were used. Other studies that have adopted factor analysis to determine construct validity include Mokhtar, Yusoff and Arshad (2009) and Owino (2014). 
Table 1

Kaiser-Meyer Olkin (KMO) and Barlett's Test

\begin{tabular}{|l|c|c|c|c|}
\multicolumn{1}{r}{ Factors } & KMO Test & \multicolumn{3}{c}{ Barlett's test of Sphericity } \\
& & Approx Chi-Square & df & Sig \\
\hline Product Strategy & .703 & 88.291 & 36 & .000 \\
\hline Pricing Strategy & .696 & 49.864 & 15 & .000 \\
\hline Promotion Strategy & .799 & 126.766 & 21 & .000 \\
\hline Place Strategy & .762 & 160.926 & 15 & .000
\end{tabular}

Source: Primary Data (2020)

The output contained in Table 1 reveals that the KMO measure of sampling adequacy for each construct ranges between .696 for price strategy and .799 for promotion strategy, suggesting that the proportion of variance may be as a result of underlying factors. Bartlett's test of sphericity was $\mathrm{p}<0.05$, an indication that the items were statistically significant. Finally, the sample size requirement was met at 69 responses. Having satisfied the minimum key requirements, it was deemed acceptable to proceed with the exploratory factor analysis (EFA).

\subsection{Exploratory Factor Analysis (EFA)}

Table 2 contains factor loadings with varimax rotation for all the 20 items used to measure marketing strategies. Four significant factors emerged from the analysis explaining $67.595 \%$ of the total variance (eigen values $>1$ ). The factor loadings ranged from 0.886 to 0.580 . Items in each factor were carefully examined so that only items with consistent meaning were retained for measuring the factors. In this study, items with factor loadings above 0.5 were retained for further analysis (Meyer, Gamst, \& Guano, 2013). Appropriateness of the four factor solution was supported by a scree test. 
Table 2

Rotated Component Matrix for Measures of Marketing Strategies (N = 69)

\begin{tabular}{|c|c|c|c|c|}
\hline Items & $\begin{array}{c}\text { Factor } 1 \\
\text { Product Strategy }\end{array}$ & $\begin{array}{c}\text { Factor } 2 \\
\text { Pricing Strategy }\end{array}$ & $\begin{array}{c}\text { Factor } 3 \\
\text { Promotion Strategy }\end{array}$ & $\begin{array}{c}\text { Factor } 4 \\
\text { Distribution Strategy }\end{array}$ \\
\hline P09 & .848 & & & \\
\hline P05 & .811 & & & \\
\hline P06 & .738 & & & \\
\hline P03 & .727 & & & \\
\hline P07 & .677 & & & \\
\hline PR1 & & .850 & & \\
\hline PR2 & & .795 & & \\
\hline PR3 & & .778 & & \\
\hline PR6 & & .740 & & \\
\hline PR4 & & .580 & & \\
\hline PRO2 & & & .886 & \\
\hline PRO4 & & & .884 & \\
\hline PRO3 & & & .798 & \\
\hline PRO5 & & & .730 & \\
\hline PRO7 & & & .671 & \\
\hline D2 & & & & .861 \\
\hline D3 & & & & .814 \\
\hline D6 & & & & .782 \\
\hline D1 & & & & .667 \\
\hline D5 & & & & .619 \\
\hline Eigen Values & 3.672 & 3.012 & 1.718 & 1.364 \\
\hline$\%$ Variance & 25.331 & 20.956 & 12.218 & 9.09 \\
\hline Cumulative \% & 25.331 & 46.287 & 58.505 & 67.595 \\
\hline
\end{tabular}

Extraction Method: Principal Component Analysis. Based on eigenvalue > 1. Rotation Method: Varimax with Kaiser Normalization

\subsection{Reliability Tests for the Extracted Factors}

Chakrabartty (2011) viewed reliability as the extent to which an assessment tool produces results that are free from errors. When a measure is reliable, the results are more accurate and it is possible to make comparisons among variables. Cronbach's alpha coefficient was used to ascertain reliability and summary findings presented in Table 3. 
Table 3

Summary of Reliability Scores

\begin{tabular}{lccc} 
& Variable & No. of Items & Cronbach's Alpha \\
\hline Product Strategy & 5 & 0.762 \\
\hline Pricing Strategy & 5 & 0.705 \\
Promotion Strategy & 5 & 0.781 \\
\hline Place (Distribution) Strategy & 5 & 0.734 \\
Export Performance & 3 & 0.696
\end{tabular}

Source: Primary Data (2020)

Cronbach's alpha values for the constructs ranged from 0.781 (Promotion Strategy) to 0.696 (Export Performance), suggesting that the test items were highly correlated and the questionnaire could therefore be used for further analysis. Hair, Black, Babin, and Anderson (2010) argue that in the social sciences field Cronbanch's alpha value of 0.6 and above is considered acceptable.

\section{STUDY RESULTS AND FINDINGS}

Out of the 90 questionnaires dispatched, only 69 questionnaires were returned, translating to a total of $76.7 \%$ response rate. This was considered adequate and compares well with other studies on export performance. Brouthers and Nakos (2005), who studied 112 Greek-owned companies, obtained a response rate of 34\%. Julian and Ahmed (2005) studied 122 Queensland export ventures attained an $18 \%$ response rate.

\subsection{Descriptive Statistics for Marketing Strategies}

This study sought to describe marketing strategies used by fresh produce firms to meet company objectives. To measure marketing strategies, the 4Ps, namely product, price, place and promotions, were identified (Kotler, 2011). Participants used a scale of 1 to 5, with 1 representing not at all (1) and (5) very large extent. Thereafter, feedback was analyzed using mean score and standard deviation. The following subsections present a summary of the output.

\subsubsection{Product Strategies}

Product characteristics influence the marketing strategies adopted by firms (O'Cass \& Julian, 2005). Mohammad, Wang and Sunayya (2012) argue that marketers should identify products characteristics that enhance consumer experience and convert them into a unique selling proposition. A total of five items were used to assess product strategy. Each attribute was rated on a scale ranging from 1 to 5 where (1) represented not at all and (5) depicted very large extent. 
Table 4

Mean Score and Standard Deviation for Measures of Product Strategies

\begin{tabular}{l|c|c|c|}
\hline \multicolumn{1}{c}{ Product Strategies } & N & Mean Score & Std. Deviation \\
\hline 1. The firm has a lot of experience with the product range & 69 & 4.35 & .682 \\
\hline 2. The company deals with products that are of superior quality & 69 & 4.28 & .639 \\
\hline $\begin{array}{l}\text { 3. The company provides quality products with a high degree } \\
\text { of consistency }\end{array}$ & 69 & 4.20 & .778 \\
\hline $\begin{array}{l}\text { The company has the capacity to meet the changing customer } \\
\text { demands when required }\end{array}$ & 69 & 3.67 & .740 \\
\hline $\begin{array}{l}\text { 5. The company offering are clearly differentiated from that } \\
\text { of competitors }\end{array}$ & 69 & 3.33 & $\mathbf{7 8 0}$ \\
\hline Average Score & $\mathbf{6 9}$ & $\mathbf{3 . 9 7}$ & $\mathbf{0 7 2}$
\end{tabular}

Source: Primary Data (2020)

The output in Table 4 shows that a large number of the participants agreed that "the firm had a lot of experience with product range" as shown by the high mean score $(\mathrm{M}=4.35, \mathrm{SD}=.682)$. According to Barkema and Drogendijk (2007), experience promotes the development of skills needed to succeed in foreign markets. That would also explain the high mean scores for items 2,4 and 5 where firms are able to produce high quality goods, meet customer changing demands, with a high degree of consistency.

\subsubsection{Pricing Strategies}

Pricing strategies are the policies adopted by firms to determine the amount to charge for goods and services. It is the only element of the marketing mix that generates sales and profits (Murray et al., 2011). Five items were used to evaluate pricing strategies used by fresh produce firms. Each attribute was rated on a scale ranging from 1 to 5 where (1) represented not at all and (5) depicted very large extent.

Table 5

Mean Score and Standard Deviation Measures of Pricing Strategies

\begin{tabular}{l|c|c|c}
\multicolumn{1}{c}{ Pricing Strategies } & N & Mean Score & Std. Deviation \\
\hline 1. The company considers market demand to determine export prices & 69 & 3.58 & 1.090 \\
\hline 2. The company does an effective job of pricing its products & 69 & 3.26 & 1.038 \\
\hline 3. The company monitors competitors' prices and price changes & 69 & 2.94 & 1.474 \\
\hline $\begin{array}{l}\text { 4. The company effectively communicates pricing information } \\
\text { to customers }\end{array}$ & 69 & 2.90 & 1.363 \\
\hline 5. The company quickly responds to competitors' pricing actions & 69 & 2.75 & $\mathbf{6}$ \\
\hline Average Score & $\mathbf{6 9}$ & $\mathbf{3 . 0 9}$ & $\mathbf{1 . 2 4}$
\end{tabular}

Source: Primary Data (2020)

The output in Table 5 reveals that participants seemed to agree that firms consider "market demand to determine export prices" as depicted by the high mean score $(\mathrm{M}=3.58, \mathrm{SD}=1.034)$. Participants also seemed to agree that firms did an "effective job of pricing products" $(\mathrm{M}=3.26$, $\mathrm{SD}=1.038$ ). Price seems to be an important element within the fresh produce industry, due to high mean scores in items 2,4 and 5. 


\subsubsection{Promotion Strategies}

Promotion strategies describe ways in which firms seek to inform and persuade their target market.

For the purposes of this study, the focus was on international trade fairs. A high mean score suggests strong agreement, while a low mean score suggests disagreement amongst the respondents.

Table 6

Mean Score and Standard Deviation for Measures of Promotion Strategies

\section{Promotion Strategies}

1. The company frequently uses international trade fairs to seek new markets

2. International trade fairs are intended to attract new customers

3. International trade fairs foster a conducive business environment, policies, tariffs and trade agreements

4. International trade fairs are intended to retain existing customers

5. International trade fairs are intended to transmit timely market information

Average Score

Source: Primary Data (2020)

\section{N Mean Score Std. Deviation}

$69 \quad 4.09 \quad .588$

$\begin{array}{lll}69 & 3.93 \quad .734\end{array}$

$\begin{array}{lll}69 & 3.77 \quad .807\end{array}$

69

3.71

.893

69

3.48

.994

3.79

.80

The findings in Table 6 indicate that participants seemed to agree that "international trade fairs are intended to seek new markets" as evidenced by the high mean score $(\mathrm{M}=4.09, \mathrm{SD}=.59)$. Respondents also concur that international trade fairs are intended to "provide timely market information" $(\mathrm{M}=3.93, \mathrm{SD}=.73)$. A possible explanation would be that trade fairs reduce buyer uncertainty and culture differences (Madsen, 1987).

\subsubsection{Place (Distribution) Strategies}

Distribution is an integral component of the marketing mix that ensures availability of products/ services at the right place and time (Vorhies \& Morgan, 2005). As with the other marketing mix components, five items were used to identify distribution strategies. Each attribute was rated on a scale ranging from 1 to 5 where (1) represented not at all and (5) depicted very large extent. Table 7 contains a summary of the findings.

Table 7

Mean Score and Standard Deviation for Measures of Place (Distribution) Strategies

\begin{tabular}{|c|c|c|c|}
\hline Distribution Strategies & $\mathbf{N}$ & Mean Score & Std. Deviation \\
\hline 1. The company attracts and retains the best suppliers & 69 & 4.23 & .573 \\
\hline 2. The company has a strong working relationship with its suppliers & 69 & 4.10 & .622 \\
\hline 3. The company is selective when choosing suppliers & 69 & 4.10 & .689 \\
\hline $\begin{array}{l}\text { 4. The company provides a high level of service support to suppliers, } \\
\text { e.g. providing seeds, timely information, etc. }\end{array}$ & 69 & 3.86 & .862 \\
\hline 5. The company is able to sell directly to end users in export markets & 69 & 3.75 & 1.008 \\
\hline Average Score & 69 & 3.58 & 1.13 \\
\hline
\end{tabular}

Source: Primary Data (2020) 
The output in Table 7 revealed that participants agreed that firms "attract and retain the best suppliers" as depicted by the high mean score $(\mathrm{M}=4.23, \mathrm{SD}=.573)$. Respondents also agreed that "a strong working relationship with suppliers" was an important attribute as shown by the high mean score $(\mathrm{M}=4.10, \mathrm{SD}=0.622)$. A possible explanation would be that suppliers within the fresh produce industry are an important link between exporters and the final consumer.

\subsection{Summary of Marketing Strategies}

To evaluate the significance of marketing strategies among fresh produce firms, a questionnaire consisting of four sections, namely product, price, place and promotion, was used and a summary of the findings is presented in Table 8. A high mean score indicates the extent to which the construct was implemented by fresh produce firms.

Table 8

Mean Score and Standard Deviation for Measures of Marketing Strategies

\begin{tabular}{llccc} 
& Marketing Strategies & N & Mean Score & Std. Deviation \\
\hline Product & 69 & 3.97 & 0.07 \\
\hline Promotion & 69 & 3.79 & 0.80 \\
\hline Place & 69 & 3.58 & 1.13 \\
\hline Price & 69 & 3.09 & 1.24 \\
Average Score & & $\mathbf{3 . 6 0}$ & $\mathbf{0 . 8 2}$
\end{tabular}

The output displayed in Table 8 shows that product strategies accounted for the highest mean score $(\mathrm{M}=3.97, \mathrm{SD}=0.07)$ followed by "promotion", which had a mean score of $\mathrm{M}=3.79$ $(\mathrm{SD}=.86)$. "Place" accounts for a mean score of $\mathrm{M}=3.58(\mathrm{SD}=1.13)$ while "price" had the least mean score of $\mathrm{M}=3.09$ ( $\mathrm{SD}=1.24)$. The average mean score for the marketing strategies construct was $\mathrm{M}=3.60$ ( $\mathrm{SD}=0.82$ ). These findings suggest that although the 4Ps made a significant contribution to the design of marketing strategies. Product comes first in terms of relative importance of the marketing mix elements.

\subsection{Diagnostic Tests}

Statistical tests are based on the assessment of underlying assumptions. For multiple linear regression, assumptions that were of primary concern were those of linearity, normality, absence of multicollinearity and homoscedasticity. All the above tests were carried out and satisfied before carrying out the regression analysis. To estimate the link between the marketing mix elements and export performance within the fresh produce industry in Kenya, marketing mix elements, namely product. pricing, promotion and place, were regressed against the dependent variable, i.e. export performance (conceptualized as a composite score of export market share, customer retention rate and return on assets (ROA)). The above analysis was conducted at 95\% confidence level (0.05) and $p$ values were used to establish the level of significance. When $p$ values were less than or equal to 0.05 , the null hypotheses was rejected in favor of the alternate hypothesis. Alternatively, when the $\mathrm{p}$ value was greater than 0.05 , then the null hypothesis was accepted. 


\section{HYPOTHESIS TEST RESULTS}

Table 9

Results of Regression Analysis

Coefficients Results on the Relationship Between Marketing Strategies and Export Performance

\begin{tabular}{|c|c|c|c|c|c|c|c|c|}
\hline & \multirow[t]{2}{*}{ Model } & \multicolumn{2}{|c|}{$\begin{array}{l}\text { Unstandardized } \\
\text { Coefficients }\end{array}$} & \multirow{2}{*}{$\begin{array}{c}\text { Standardized } \\
\text { Coefficients } \\
\text { Beta }\end{array}$} & \multirow[t]{2}{*}{$\mathbf{t}$} & \multirow[t]{2}{*}{ Sig. } & \multirow{2}{*}{$\begin{array}{c}\text { Collinearity } \\
\text { Tolerance }\end{array}$} & \multirow{2}{*}{$\begin{array}{c}\text { Statistics } \\
\text { VIF }\end{array}$} \\
\hline & & B & Std. Error & & & & & \\
\hline \multirow{5}{*}{.1} & (Constant) & -4.273 & 1.206 & & -3.543 & .001 & & \\
\hline & Product & .689 & .285 & .281 & 2.418 & .018 & .702 & 1.424 \\
\hline & Price & .373 & .265 & .161 & 1.406 & .004 & .721 & 1.386 \\
\hline & Place (Distribution) & .393 & .182 & .240 & 2.160 & .035 & .773 & 1.294 \\
\hline & Promotion & .553 & .241 & .232 & 2.299 & .025 & .937 & 1.068 \\
\hline
\end{tabular}

${ }^{a}$ Dependent Variable: Export Performance

The $\mathrm{p}$ values for product $(.02)<0.05$, price $(.00)<0.05$, place (distribution) $(.04)<0.05$ and promotion $(.02)<0.05$ suggest that all the elements, namely product, price, place and promotion, made a statistically significant contribution to the model and were therefore good predictors of export performance. The standardized beta value for product is .281 , for price it is .161, for place (distribution) it is .240 and for promotion it is .232. Product has the largest impact amongst the independent variables.

Table 10

Model Summary on the Relationship between Marketing Strategies and Export Performance

\begin{tabular}{|c|c|c|c|c|}
\hline Model & R & R Square & Adjusted R Square & Std. Error of the Estimate \\
\hline 1. & $.626^{\mathrm{a}}$ & .392 & .353 & .835 \\
\hline
\end{tabular}

a Predictors: (Constant), Product, Price, Place (Distribution), Promotion,

Dependent Variable: Export Performance

Source: Primary data

The results in the table revealed that the $\mathrm{R}^{2}$ value for model 1 is 0.392 , which implies that $39.2 \%$ of the variation in export performance could be explained by marketing strategies.

Table 11

ANOVA Results on the Relationship between Marketing Strategies and Export Performance

\begin{tabular}{|c|c|c|c|c|c|c|}
\hline & Model & Sum of Squares & df & Mean Square & $\mathbf{F}$ & Sig. \\
\hline \multirow{3}{*}{1} & Regression & 28.734 & 4 & 7.183 & 10.294 & $.000^{\mathrm{b}}$ \\
\hline & Residual & 44.659 & 64 & .698 & & \\
\hline & Total & 73.393 & 68 & & & \\
\hline
\end{tabular}

b Predictors: (Constant), Product, Price, Place (Distribution), Promotion,

Dependent Variable: Export Performance

Source: Primary data

The F statistic is used to test the significance of the regression model. The ANOVA results shown in the table indicate that the model significantly predicts export performance: $F(4,64)=10.294$, $\mathrm{p}(.00)<.05$. This is evidenced by the $\mathrm{p}$ value which is less than .05 for the predictor variables. 
Table 12

Summary of the Hypothesis Results

\begin{tabular}{l|c|c}
\multicolumn{1}{c}{ Research Hypothesis } & P value & Decision \\
\hline $\begin{array}{l}\mathrm{H}_{1} \text { : Product strategies adopted by firms have no significant influence } \\
\text { on their export performance }\end{array}$ & .02 & Null hypotheses was rejected \\
\hline $\begin{array}{l}\mathrm{H}_{2} \text { : Price strategies adopted by firms have no significant influence } \\
\text { on their export performance }\end{array}$ & .00 & Null hypotheses was rejected \\
\hline $\begin{array}{l}\mathrm{H}_{3} \text { : Promotion strategies adopted by firms have no significant } \\
\text { influence on their export performance }\end{array}$ & .02 & Null hypotheses was rejected \\
$\begin{array}{l}\mathrm{H}_{4} \text { : Place strategies adopted by firms have no significant influence } \\
\text { on their export performance }\end{array}$ & .04 & Null hypotheses was rejected
\end{tabular}

\section{DISCUSSION OF FINDINGS}

The current study sought to establish the link between marketing strategy and export performance of fresh produce firms in Kenya. The results established that the four elements, namely product, price, place and promotion, of marketing strategy influenced performance of fresh produce firms in the export market. The findings from regression analysis revealed that $39.2 \%$ of the variation in export performance could be explained by marketing strategies while $60.8 \%$ of the variability could be determined by other factors not captured in the model. This results are consistent with findings of previous research. For instance, Batavia and Kolachi (2012) argued that marketing strategies were crucial in ensuring competitiveness of firms in foreign markets. Similar results were obtained by Sezgin, Uray and Burnaz (2015), who examined the link between marketing strategy and export performance of Turkish clothing firms.

These results further established that product strategy made the largest contribution to export performance. A possible explanation would be that the key customers for fresh produce firms were essentially resellers; for this reason, when product-related advantages (quality, consistency) were achieved, export customers were willing to pay premium prices translating to higher profits. Another possibility could be stringent measures imposed on aspects such as traceability and good agricultural practices (GAP).

A finding that was not anticipated was the relatively low mean of the price element compared to the other marketing elements, namely product, place and promotion. It appears that fresh produce firms did not use price as a competitive weapon. A possible explanation could be that the demand for fresh produce in the export market could be inelastic, where changes in the price of fresh produce did not influence demand. This usually applies to products that are classified as necessities and do not have substitutes.

\section{CONCLUSION}

This study made a contribution to export literature by looking at the relationship between marketing strategies and export performance of fresh produce firms in Kenya. Several conclusions are drawn from the study findings. The first is that marketing strategies made a significant and positive contribution to export performance of fresh produce firms in Kenya. The results also revealed that among the four elements of marketing strategy, fresh produce firms in Kenya regard product strategy as the most significant element when developing and implementing the marketing mix strategy. 
From the practitioners point of view, the findings from this study confirmed that marketing strategies had a positive influence on export performance. For this reason, managers should increase export performance by developing and implementing competitive marketing strategies. However, the degree of emphasis placed on the 4Ps varies with more emphasis placed on the product strategy.

At the policy level, the government and key stakeholders can stimulate regular export business at the firm level by lobbying for regional and bilateral trade agreements that seek to increase markets for fresh produce firms.

\section{RECOMMENDATION}

Although the findings in this study contribute to the understanding of the relationship between marketing strategies and export performance, a broader study that includes more developing countries/multiple industries would provide an important extension to this study and would also help in the generalization of research findings.

This study focused on identifying the role of marketing strategies (product, price, place and promotion) in achieving export success within the fresh produce industry. Due to the nature of product, the findings could not be generalized to the service industry, which displays unique characteristics such as intangibility and heterogeneity.

\section{References}

Abou-Strait, F. (2005). Are exports the engine of economic growth? An application of cointegration and causality analysis for Egypt, 1977-2003 (Economic Research Working Paper). African Development Bank.

Adetayo, J.O. (2006). Marketing - Concepts and applications. Ile-Ife: Akin's Printing Press.

Adis, A.A. (2010). Export performance on the Malaysian wooden furniture industry: An empirical study. Journal of International Food \& Agribusiness Marketing, 22(1-2).

https://doi.org/10.1080/08974430903372773

Babbie, E. (2010). The practice of social research. London: Wadsworth Cengage Learning.

Barkema, H.G., \& Drogendijk, R. (2007). Internationalising in small, incremental or larger steps?. Journal of International Business Studies, 38, 1132-1148. https://doi.org/10.1057/palgrave.jibs.8400315

Batavia, A.R., \& Kolachi, N.A. (2012). Impact of export marketing strategies on organizational performance: Evidences from Pakistani textile sector. Interdisciplinary Journal of Contemporary Research in Business, $4(2), 72-80$.

Belch, G.E., \& Belch M.A. (2007). Introduction to advertising and promotion. An integrated marketing communication perspective (3rd ed.). Boston: Irwin.

Bianchi, C., \& Garcia, R. (2007). Export marketing strategies of an emerging country: An exploratory study of the main challenges and factors leading to success for Chilean food exporters. Journal of Food Products Marketing, 13(3), 1-19. https://doi.org/10.1300/J038v13n03_01

Blattberg, R.C., \& Scott A.N. (1990). Sales promotion: Concepts, methods, and strategies. Englewood Cliffs, NJ: Prentice Hall.

Bowersox, D., \& Closs, D.J. (1996). Logistic management: An integrated supply chain process. New York: McGraw-Hill.

Brouthers, L.E., \& Nakos, G. (2005). The role of systematic international market selection on small firms' export performance. Journal of Small Business Management, 43(4), 363-381. https://doi.org/10.1111/j.1540-627X.2005.00142.x

Cavusgil, S.T., \& Zou, S. (1994). Marketing strategy-performance relationship: An investigation of the empirical link in export market ventures. Journal of Marketing, 58(1), 1-21. https://doi.org/10.1177/002224299405800101

Chakrabartty, S.N. (2011). Measurement of reliability as per definition. In Prooceedings of the Conference on Psychological Measurement: Strategies for the New Millenium (pp. 116-125). School of Social Sciences, Indira Gandhi National Open University, New Delhi. 
Chang, Y.S., \& Fang, S.R. (2015). Enhancing export performance for business markets: Effects of inter organizational relationships on export market orientation (EMO). Journal of Business to-Business Marketing, 22(3), 211-228. https://doi.org/10.1080/1051712X.2015.1081014

Chen, J., Sousa, C.M.P., \& He, X. (2016). The determinants of export performance: A review of the literature 2006-2014. International Marketing Review, 33(5), 626-670. https://doi.org/10.1108/IMR-10-2015-0212

Chung, H.F.L. (2008). The impact of a centralised organisational structure on marketing standardisation strategy and performance: The experience of price, place and management processes. Journal of Global Marketing, 21(2), 83-107. https://doi.org/10.1080/08911760802135152

Coviello, N.E., Winklhofer, H., \& Hamilton, K. (2006). Marketing practices and performance of small service firms: an examination in the tourism accommodation sector. Journal of Service Research, 9(1), 38-58. https://doi.org/10.1177/1094670506289533

Cunha, R.D., \& Rocha, T.V. (2015). Export marketing strategy and performance among micro and small Brazilian enterprises. Entrepreneurship in international marketing. Advances in International Marketing, 25(1), 129-159. https://doi.org/10.1108/S1474-797920140000025006

Fang, E., \& Zou, S. (2009). Antecedents and consequences of marketing dynamic capabilities in international joint ventures. Journal of International Business Studies, 40(5), 742-761. https://doi.org/10.1057/jibs.2008.96

GoK. (2017). Kenya climate smart agriculture strategy 2017-2026. Ministry of Agriculture, Livestock and Fisheries, Government of Kenya.

Hair, J.J., Ringle, C., \& Sarstedt, M. (2011). PLS-SEM: Indeed a silver bullet. The Journal of Marketing Theory and Practice, 19(2), 139-152. https://doi.org/10.2753/MTP1069-6679190202

Hawkins, M. (2011). Consumer behavior: Building marketing strategy (11th ed.). New York: McGraw-Hill/Irwin.

Hinterhuber, A., \& Liozu, S.M. (2013). Innovation in pricing: Contemporary theories and best practices. New York: Routledge. https://doi.org/10.4324/9780203085684

Horticultural Crops Development Authority, HCDA. (2009). Strategic plan, 2009-2013. Nairobi, Kenya.

Israel, G.D. (1992, November). Determining sample size. Fact Sheet PEOD-6.

Jones, M.V. (2001). First steps in internationalisation: Concepts and evidence from a sample of small high technology firms. Journal of International Management, 7(3), 191-210. https://doi.org/10.1016/S1075-4253(01)00044-8

Julian, C.C., \& Ahmed, Z.U. (2005). The impact of barriers to export on export marketing performance. Journal of Global Marketing, 19(1), 71-93. https://doi.org/10.1300/J042v19n01_05

Kabano, G. (2017). Antecedents of standards compliance for the internationalisation of Kenyan horticulture (Unpublished doctoral thesis). School of Business, United States International University-Africa.

Katsikeas, C., Leonidou, L., \& Morgan, N. (2000). Firm-level export performance assessment: Review, evaluation and development. Academy of Marketing Science, 28(4), 493-511. https://doi.org/10.1177/0092070300284003

KDLC. (2010). Smallholder farmers' involvement in commercial horticulture Kenya's perspective. Kenya Development Learning Centre (KDLC).

Kenya National Bureau of Statistics. (2018). Economic survey. Nairobi: Kenya National Bureau of Statistics. Government of the Republic of Kenya.

Kimwomi, K.H. (2014). Knowledge strategy, organizational characteristics, innovation and performance of manufacturing firms in Kenya (Doctoral thesis). School of Business, University of Nairobi, Kenya.

Köksal, H.M., \& Kettaneh, T. (2011). Export problems experienced by high- and low-performing manufacturing companies: A comparative study. Asia Pacific Journal of Marketing and Logistics, 23(1), 108-126. https://doi.org/10.1108/13555851111100021

Kotler, P. (1977). From sales obsession to marketing effectiveness. Harvard Business Review, 55(6), 67-75.

Kotler, P. (1989). From mass marketing to mass customization. Planning Review, 17(5), 10-1347. https://doi.org/10.1108/eb054267

Kotler, P. (2011). Reinventing marketing to manage the environmental imperative. Journal of Marketing, 75(4), $132-135$ https://doi.org/10.1509/jmkg.75.4.132

Kotler, P., \& Armstrong, G. (2005). Marketing: An introduction. New Jersey: Pearson Education, Inc. Kotler, P., \& Armstrong, G. (2014). Marketing: An introduction. New Jersey: Pearson Education Inc. 
Lages, F., \& Sousa, C. (2010). Export performance. In Wiley International Encyclopedia of Marketing. John Wiley \& Sons, Ltd. https://doi.org/10.1002/9781444316568.wiem06029

Lages, L.F., \& Lages, C.R. (2004). The STEP scale: A measure of short-term export performance improvement. Journal of International Marketing, 12(1), 36-56. https://doi.org/10.1509/jimk.12.1.36.25647

Leonidou L.C., Katsikeas C.S., \& Coudounaris D.N. (2010). Five decades of business research into exporting: A bibliographic analysis. Journal of International Management, 16(1), 78-91. https://doi.org/10.1016/j.intman.2009.06.001

Lisboa, A., Skarmeas, D., \& Lages, C. (2013). Export market exploitation, exploration and performance: Linear, moderated, complementary and non-linear effects. International Marketing Review, 30(3), 211-230. https://doi.org/10.1108/02651331311321972

Madsen, T.K. (1987). Empirical export performance studies: a review of conceptualizations and findings. In S.T. Cavusgil \& C. Axinn (Eds.), Advances in International Marketing, 2(1), 177-98.

Mallen, B. (1977). Principles of marketing channel management. Lexington, Mass.: Lexington Books.

McCarthy, E.J. (1964). Basic marketing. IL: Richard D. Irwin.

Meyer, L.S., Gamst, G., \& Guarino, A.J.(2013). Applied multivariate research design and interpretation. California, USA: Sage Publications Inc.

Mohammad, A.H., Wang, A., \& Sunayya, B. (2012). Investigating on tourists satisfaction: An empirical study on East Lake. European Journal of Business and Management, 4(7), 21-32.

Mokhtar, S.S.M., Yusoff, R.Z., \& Arshad, R. (2009), Market orientation critical success factors of Malaysian manufacturers and its impact on financial performance. International Journal of Marketing Studies, (1), 77-84. https://doi.org/10.5539/ijms.v1n1p77

Morgan, N.A., Katsikeas, C.S., \& Vorhies, D.W. (2012). Export marketing strategy implementation, export marketing capabilities, and export venture performance. Journal of the Academy of Marketing Science, 40(2), 271-289. https://doi.org/10.1007/s11747-011-0275-0

Murray, J., Gao, G., \& Kotabe, M. (2011). Market orientation and performance of export ventures: The process through marketing capabilities and competitive advantages. Journal of the Academy of Marketing Science, $39(2), 252-269$.

https://doi.org/10.1007/s11747-010-0195-4

Myers, M.B. (1997). The pricing of export products: Why aren't managers satisfied with the results. Journal of World Business, 32(3), 277-289. https://doi.org/10.1016/S1090-9516(97)90012-2

Namiki, N. (2008). A taxonomic analysis of export marketing strategy: an exploratory study of US exporters of electronic products. Journal of Global Marketing, 8(1), 27-50. https://doi.org/10.1300/J042v08n01_03

Navarro, A., Losada, F., Ruzo, E., \& Diez, J.A. (2010). Implications of perceived competitive advantages, adaptation of marketing tactics and export commitment on export performance. Journal of World Business, 45(1), 49-58. https://doi.org/10.1016/j.jwb.2009.04.004

Njeru, W.G. (2013). Market orientation, marketing practices, firm characteristics, external environment and performance of tour firms in Kenya (Unpublished doctoral thesis). School of Business, University of Nairobi.

Nthege, D.M. (2019). Marketing strategies, firm characteristics, customer perception and performance of food and beverage processing companies in Kenya (Doctoral thesis). School of Business, University of Nairobi.

O’Cass, A., \& Julian, C.C. (2005). Examining firm and environmental influences on export marketing mix strategy and export performance of Australian exporters. European Journal of Marketing, 37(3/4), 366-384. https://doi.org/10.1108/03090560310459005

Odiko, S.Y (2018). International marketing strategies and performance of tour firms in Kenya. Stratford Journals, $1(2), 42-67$.

Ogbu, C.P. (2015). Application of marketing strategies in Nigerian quantity surveying firms. Journal of Economics and Sustainable Development, 6(16), 30-43.

Okpara, J. (2009). Entrepreneurial orientation and export performance: Evidence from an emergent economy. International Review of Business Research Papers, 5(6), 195-221.

Owino, J.O. (2014). Organizational culture, marketing capabilities, market orientation, industry competition and performance of microfinance institutions in Kenya (Unpublished doctoral thesis). School of Business, University of Nairobi, Kenya.

Palmer, A. (2011). Principles of services marketing (3rd ed.). UK: McGraw-Hill Publishing Company.

Rad, H.S., \& Akbari, Z. (2014). The role of brand and advertising in marketing mix (A review of marketing mix). Interdisciplinary Journal of Contemporary Research in Business, 6(7), 114-127.

Rosenbloom, B. (1990). Motivating your international channel partners. Business Horizons, 33(2), 53-57. https://doi.org/10.1016/0007-6813(90)90010-9 
Satish, P. (2006). P\&G announces Pampers now a bigger disposable. The Cincinnati Post. E. W. Scripps Company.

Saunders, M., Lewis, P., \& Thornhill, A. (2011). Research methods for business students (2nd ed.). New Delhi: Pearson.

Sezgin. S., Uray. N., \& Burnaz. S. (2015). Marketing practices and performance of the Turkish clothing industry exporting to the European Union. Globalization, the Multinational Firm and Emerging Economies, 10(1), 163-190.

https://doi.org/10.1016/S1474-7979(00)10010-9

Shimp, T.A. (2003). Advertising, promotion and supplemental aspects of integrated marketing communication. (6th ed.). Mason, OH: South-Western.

Shoham, A., \& Kropp, F. (1998). Explaining international performance: Marketing mix, planning, and their interaction. Marketing Intelligence \& Planning, 16(2), 114-123. https://doi.org/10.1108/02634509810209641

Sousa, C.M.P., \& Bradley, F. (2005). Antecedents of international pricing adaptation and export performance. Journal of World Business, 43(3), 307-320. https://doi.org/10.1016/j.jwb.2007.11.007

Varadarajan, P.R. (2015). Strategic marketing, marketing strategy and market strategy. Journal of the Academy of Marketing Science, 5(3-4), 78-90. https://doi.org/10.1007/s13162-015-0073-9

Vorhies, D.W., \& Morgan, N.A. (2005). Benchmarking marketing capabilities for sustainable competitive advantage. Journal of Marketing, 69(1), 80-94. https://doi.org/10.1509/jmkg.69.1.80.55505

Wanjiru, M.K. (2018). Effect of food value chain governance. Determinants on competitive advantage of fresh fruits and vegetable exporters in Kenya (Unpublished doctoral thesis). School of Business, Jomo Kenyatta University of Agriculture and Technology.

Zou, S., \& Stan, S. (1998). The determinants of export performance: A review of the empirical literature between 1987 and 1997. International Marketing Review, 15(5), 333-56.

https://doi.org/10.1108/02651339810236290 


\section{APPENDIX A}

\section{CODES AND ITEMS USED IN THE STUDY}

\begin{tabular}{|c|c|}
\hline CODES & Items of Product Strategies \\
\hline $\mathrm{P} 01$ & The company has the ability to engage in value addition to its products \\
\hline P02 & The company ventures in products that have a broad market appeal \\
\hline $\mathrm{P} 03$ & The company offering is clearly differentiated from that of competitors \\
\hline P04 & The company offers a broad product variety \\
\hline P05 & The company deals with products that are of superior quality \\
\hline P06 & The company provides quality products with a high degree of consistency \\
\hline P07 & The company has the capacity to meet the changing customer demands when required \\
\hline P08 & The firm has strong concerns about developing brand identity \\
\hline P09 & The firm has a lot of experience with the product range \\
\hline CODES & Items of Pricing Strategies \\
\hline PR1 & The company considers market demand to determine export prices \\
\hline PR2 & The company does an effective job of pricing its products \\
\hline PR3 & The company monitors competitors' prices and price changes \\
\hline PR4 & The company quickly responds to competitors, pricing actions \\
\hline PR5 & The company effectively communicates pricing information to customers \\
\hline PR6 & The company knows the competitors' pricing tactics \\
\hline CODES & Items of Pricing Strategies \\
\hline PRO1 & The company frequently attends international trade fairs in Europe and UAE \\
\hline $\mathrm{PRO} 2$ & International trade fairs are intended to attract new customers \\
\hline PRO3 & $\begin{array}{l}\text { International trade fairs foster a conducive business environment, policies, tariffs and trade } \\
\text { agreements }\end{array}$ \\
\hline PRO4 & International trade fairs are intended to seek new markets for the company produce \\
\hline PRO5 & International trade fairs are intended to retain existing customers \\
\hline PRO6 & International trade fairs involve the company targeting a specific market segment(s) or customer \\
\hline PRO7 & International trade fairs are intended to provide timely market information \\
\hline CODES & Items of Place (Distribution) Strategies \\
\hline D1 & The company has a strong working relationship with its suppliers \\
\hline D2 & The company attracts and retains the best suppliers \\
\hline D3 & $\begin{array}{l}\text { The company provides a high level of service support to suppliers, e.g. providing seeds, timely } \\
\text { information, etc. }\end{array}$ \\
\hline D4 & The company is able to sell directly to end users in export markets \\
\hline D5 & The company provides training to its suppliers \\
\hline D6 & The company is selective when choosing suppliers \\
\hline
\end{tabular}

